\title{
Beef Cattle Value Chain Map in Nono Benja Distirict, Jimma Zone, Oromia Regional State, Ethiopia
}

\author{
Gemechu Degefa Yadata* Adeba Gemechu (PhD) Amsalu mitiku (associate professor) \\ Oromia State University collage of development studies Department of Agribusiness and Value Chain \\ Management
}

\begin{abstract}
Ethiopia ranks first in Africa and tenth in the world for livestock population and cattle take the lion share of this population of the country. This study was conducted in Nono benja district of Jimma zone, Oromia regional state, Ethiopia with the aim of analyzing beef cattle value chain. The specific objectives were identifying value chain actors, role and their linkage, quantifying value share of actors, Two stage sampling methods were employed to select producers and data were collected from both primary and secondary sources. Primary data were collected from 154 producers, and 20 small traders, 5 large traders, 6 butchers, 8 hotels /restaurants/ and 30 consumers while secondary data were collected from the district and other government organizations. Descriptive statistics and econometric model were used. The finding of the study revealed that, input suppliers, producers, large traders, butchers, small traders, hotel and restaurants, and consumers were the main actors of beef cattle value chain. The profit share of actors in beef cattle value chain revealed that about $29.9 \%$ and $26.87 \%$ was shared by large trader and small trader. While producer's butchers, hotel and restaurant and small traders shared $15.26 \%, 14.96 \%$ and $12.93 \%$ respectively. The analysis of marketing share of actors was the highest at channel VI which is about 38.9 $\%$ and lowest $2.1 \%$ at channel I. Generally, the existing situation for beef cattle sector with regard to its value chain analysis, integration and coordination is not well stimulated in the area. Therefore, policy aiming at facilitating producer's education, distance to the market, use credit, access to market information, distance to feed resources, number of livestock owned, strengthening the existing sector and improving linkage of chain actors are recommended to enhance the development of beef cattle value chain at Nono benja district of south western, Ethiopia.
\end{abstract}

Keywords: Value Chain, actors, beef cattle, Share and Nono Benja district.

DOI: $10.7176 / \mathrm{JBAH} / 10-11-01$

Publication date:June $30^{\text {th }} 2020$

\section{INTRODUCTION}

\subsection{Background}

The majority of the world's estimated 1.3 billion poor people live in developing countries where they depend directly or indirectly on livestock for their livelihoods (World Bank, 2013 and FAO, 2012). Globally, livestock contributes about 40 percent to the agricultural gross domestic product (GDP) and constitutes about 30 percent of the agricultural GDP in the developing world (World Bank, 2013). They keep livestock and use them in a variety of ways that extend far beyond income generation. In many cases, livestock are a central component of smallholder risk management strategies (Bailey et al., 2015).

The sector plays a major role in the national economy and it is the source of income and employment for the rural population (Nigussie, 2014). Livestock production is an integral part of Ethiopia's agricultural sector and plays a vital role in the national economy. At present, livestock contributes about $20 \%$ of the GDP, supporting the livelihoods of $70 \%$ of population and generating about $11 \%$ of annual export earnings. As the country has a large livestock population, which ranks first in Africa and tenth in the world, it has much to gain from the growing global markets for livestock products (SPS-LMM, 2010).

Global beef production was estimated at 55 million tons in 2010 (FAPRI-ISU, 2015), with 75 percent of this beef being produced in Brazil, China, the EU and the United States. The longer-term outlook for global beef demand is, however, positive, with a rise in beef demand of 10 million tons forecast over the next decade (Rabobank, 2010). There is an urgent need to improve livestock productivity in Ethiopia in order to keep pace with expected increase in demand for livestock products. Demand for beef in sub-Saharan Africa, almost doubled over the past two decades. The same trend has been observed in eastern Africa. Unfortunately, livestock productivity remains very low compared to other parts of the world because producers are beset by several technical, institutional and infrastructural constraints related to feeding, animal health and genotype (Oume et al., 2010).

In 2008/09, Ethiopian sedentary private holdings were estimated at about 49 million heads of cattle (CSA, 2009). Potential areas identification and effective documentation of traditional practices are excellent premises for improvement of the beef sector in Ethiopia. like most of the countries in sub-Saharan Africa, is heavily dependent on agriculture. The agricultural sector plays an important role in the overall development of the country's economy. The sector plays a major role in the national economy and it is the source of income and employment for the rural population (Nigussie, 2014). 
The recent livestock population of Ethiopia estimates that the country has about 52.1 million heads of cattle, 24.2 million sheep, 22.6 million goats and 44.9 million poultry (MOA, 2013; Berihu et al., 2014). The majority of the world's rural poor, and a significant proportion of the urban poor, keep livestock and use them in a variety of ways that extend far beyond income generation. The roles livestock play in developing countries, especially to rural livelihood improvement and augmenting livelihood of poor, are well recognized (Upton, 2014).

Primarily, livestock provide draft power, food, income, transportation, alternative energy sources (dung cake for fuel and biogas), social prestige and status in communities. Livestock production creates income opportunities for landless poor who provide fodder, collect water to feed and engage in value addition and marketing. Livestock and their products are estimated to compose a third of total value of agricultural gross output in developing countries and this share is rising from time to time (ILRI, 2008).

According to MOFED (2009) and World Bank (2002) the economic contribution of the livestock sub-sector in Ethiopia is also about $15 \%$ to $17 \%$ of GDP and $35 \%$ to $49 \%$ of agricultural GDP, and 37 to $87 \%$ of the household incomes. Formally, Ethiopia exports about 472,000 Livestock annually (MoA, 2011 and LLC, 2011). This is significantly higher than the annual official exports of cattle (12,934 head), sheep (13,554 head) and goats $(1,247$ head) between 1998 and 2003 (Kefyalew,2011). In Ethiopia, recent studies estimated that annual illegal flow of livestock through boundaries reaches as high as 575,000 cattle, 1,150.000 Shoats \& 126,500 Camel (Solomon et al., 2010 and LMD Research, 2013).

Particularly highland mixed crop-livestock farming system of Ethiopia support 2/3 of the livestock population and hold about $95 \%$ of the cropped area. It is estimated that the highlands contain nearly 75 to $80 \%$ of the national cattle and sheep, and $30 \%$ of the national goat flock (Hailesilassie, 2016). His being the potential for export, the actual performance has remained very low, leaving most ( 55 to $85 \%$ ) of the projected livestock off take for the unofficial cross-border export and the domestic market.

Among this Nono Benja district cattle accounted 230,000 sheep's 65,000 goats, 36,000and equines 55,127 (Nono benja livestock development offices,2017). Value chain analysis facilitates an improved understanding of competitive challenges, helps in the identification of relationships of actors and coordination mechanisms, and assists in understanding how chain actors deal with powers and who governs or influences the chain. Similarly, it is also essential to explain the connection between all the actors in a particular chain of production and distribution and it shows who adds value more and where, along the chain. It helps to identify pressure points and make improvements in weaker links where returns are low (Gashahun, 2015).

\subsection{Statement of the Problem}

The livestock sector in Ethiopia plays a vital role in the overall development of the country's economy. Yet, the existing income generating capacity of livestock as compared to its immense potentials in the country is not encouraging. Under these conditions, farmers have no incentives to improve the quality of their animals through appropriate management practices (Solomon, 2004). To enhance opportunities for value chain actors, we need to understand the main value chain actors affecting the entire value chain (Berhanu, 2012).

Fattening cattle mainly constitute draught oxen as they are usually used for draught work before fattening commence, even though; very few instances of purchasing cattle directly for fattening were reported. Besides draught oxen, sterile females and cows with poor production and reproduction performances are fed for finishing (Takele et al., 2009). Only a small fraction of Ethiopian beef is raised in feedlots and smallholders throughout the country fatten the vast majority of cattle in backyard systems.

The backyard fattening is cheaper than feedlot operation, but cannot supply large and consistent volumes to a commercial abattoir or trader. This in turn is reported to limit both investment and commitment to individual backyard producers. However, feedlot operators reported that they could not sell to local butchers' shops, as they cannot compete on price with backyard fattening (Sintayehu et al., 2013). In Ethiopia, beef is supplied from extensively managed herds. This is maintained from culls and surplus males. There is no as such special program implemented for beef production.

Therefore, for the development of the Ethiopian beef cattle industry feeding and management strategies and coordination of the actors should be enhanced. On the other hand, selection of indigenous cattle should be practiced to develop excellent indigenous beef breeds (Takele et al., 2009). In Ethiopia fewer cattle are slaughtered than any other animals, even with most butcheries selling only beef and the meat intake remained with consuming $9 \mathrm{~kg}$ per capita annually (FAOSTAT, 2004). Ethiopia's domestic meat consumption for 2006-07 has been estimated at 2.4 $\mathrm{kg} / \mathrm{capita}$ per year for beef.

Systematic identification of constraints faced by beef cattle value chain is increasingly seen by agricultural research as important component of any strategy for reaching the Millennium Development Goals (MDG) (Giuliani and Pietrobelli, 2005). Such information provides useful insights towards the designing and implementation of strategies to alleviate the shortage of quality beef cattle supply in the market (Gebremariam et al., 2013)

Lack of market information particularly price and supply situations is one of the main contributing factors to 
livestock market inefficiency in Ethiopia most farmers in the country do not have easy access to marketplace due to this, they travel long distance to sale their animals (Million, 2014).

Even though the high potential of beef cattle production in study areas the producers use as a source of cash income from their animal they should have to be known season of production and time of high demand of their beef in each value chain actors throughout the beef value chain of the country. In general, and the study area in particular, they are not considered well and acknowledged by the responsible bodies to upgrade the commodity transformation into better stage and which can pay back positive return to the whole economy.

In this regard, beef value chain analysis is an interesting process but as far as known very limited investigation has been done in the study area. Under such circumstances, a study that focused on production and marketing problems, and roles and responsibilities of actors can play significant role towards the improvements of the existing system.

In the study area market linkage service like; relation among producers, traders controlling mechanisms, market information and price settings are weak and it need critical investigation. Value chain analysis enables to understand the relationship among input suppliers, producers and other actors. Despite, this study was aimed to fill information gaps in beef value chain actors and linkage in terms of value share of actors and chain governance, their contribution and benefit share, factors affecting quantity market supply of beef cattle and constraints and opportunities of beef cattle value chain in the study areas.

Therefore, this study helps to narrow the research gap on the subject and contribute towards improvement of strategies for reorienting value chain system and helps to generate information that can help as input for making an informed intervention to improve the system.

\subsection{Research Questions}

1. Who are the major actors in beef value chain and what is their function and linkage?

2. What are the benefits shared in value chain has been distributed across the chain?

\subsection{Objectives of the Study \\ 1.4.1. General objective}

The study was to analyze beef value chain in Nono Benja district, Jimma Zone Oromia regional state, Ethiopia.

\subsubsection{Specific objectives}

$\checkmark$ To identify and map the beef value chain actors, their function and linkage in study area.

$\checkmark \quad$ To identify the benefit, share of each actor in beef value chain in the study area.

\section{2 value chain analysis}

\subsubsection{Beef cattle value chain actors and their function}

The value chain map highlighted the involvement of diverse actors who are participated directly or indirectly in the value chain. The direct actors are those involved in business activities in the chain (input suppliers, producers, traders, butchers, hotel /restaurants/ and consumers) and indirect actors are those that provide financial or nonfinancial support services, such as credit agencies, business service providers and government, cooperatives, researchers and extension agents.

\subsubsection{Value chain actors and their roles}

The direct actors in beef cattle value chain in District were input suppliers, producers, small trader's large traders, butchers, hotel or restaurants, and consumers. Producers were producing beef and beef cattle products in study area. Each of these actors adds value to beef cattle products. The direct actors play crucial role along beef value chain and their major activities were identified as follows; -

\section{Input suppliers}

The beef cattle products value chain in the study area starts from the concept of design of products from production with use of inputs to consumers and distribution of value added beef cattle products. Inputs which are supplied by input suppliers in study area include improved variety of grass, industrial by products, veterinary medicines and vaccination of beef cattle in study area. Agricultural office and livestock development office are the major input suppliers that play a great role in the study area to encourage beef cattle value addition along beef value chain.

A. Beef cattle: Beef cattle fatteners in the study areas use different inputs for beef cattle fattening practices. The major and the first input for beef cattle fattening is the beef cattle itself. The beef cattle are obtained from the two main sources such as using the retired oxen after plowing season and buying from the market. Sometimes some of the beef cattle fatteners also take beef cattle from their relatives and rich people with the agreement that to share only the profit equally with the owner of the beef cattle after sale and to provide the original purchase cost of the beef cattle to the owner.

B. Land: Land is the basic factor of production and serves as a base input for the others to stand on and produce a certain output. Beef cattle fatteners in the study areas have their own land with limited size on average 3.042ha according to the result and most of them use this land for cropping and feeding the left overs of the crops, the 
grasses grown in between the crops as well as some parts of crops to their beef cattle and some of them also use a parcel of land for grazing.

C. Feeds: As the beef cattle fatteners in the study areas mainly practice the Traditional and Hararghe fattening system, they use feeds around their homestead. The common feeding practices used by beef cattle fatteners in the study areas are some of them graze on their own land, buying grasses from other neighbors and feeding on the cereal crops straw and by-products, and by-products of other crops like root and tuber crops, vegetables, fruit crops. Fatteners also buy feed salt for their beef cattle from the market.

D. Water: This is an important input in the beef cattle fattening practices. The participants in the beef cattle fattening practices reported that water is the major problem in the study areas especially during the dry season. Therefore, it requires great attention to use the underground water for beef cattle fattening as well as for the other purposes in the coming future in the study areas.

E. Drugs: Beef cattle fatteners use different drugs for their beef cattle during fattening period. As they mentioned during the survey period they use drugs in different forms such as tabulates, vaccines, etc. for their beef cattle. Sometimes they incur high costs for drugs during the fattening season specially when there is severity of diseases occur in the study areas.

F. Beef cattle house: Like in other rural parts of our country, house for the beef cattle is the most important issue in the study areas. Such cases are may be common in most parts of the rural areas of the poor or under developing countries through-out the world. However, practices like giving separate rooms for beef cattle in the study areas are good practices or good starting points until we arrive at providing the separate houses for beef cattle in coming near future.

\section{Producers}

The major actors who perform most of the value chain functions right from farm inputs preparation on their farms of the inputs from other sources up to handling and marketing. The major value chain functions that beef cattle producers perform include rearing, producing, disease controlling, fattening and transporting and marketing.

\section{Small traders}

There are (20) small traders that were working in the District. These are traders who collect beef cattle from farmers in village markets and from farms for the purpose of reselling it to large traders, butchers and consumers. They use their financial resources and their local knowledge to number of beef cattle from the surrounding area. They play important role and they do know areas of supply well. Small traders are the key actors in the beef cattle value chain, responsible for the trading from production areas to large traders and markets in the study areas. The trading activities of collectors include buying and transporting and selling to large traders, butchers, hotel/restaurants and consumers.

\section{Large traders}

There are five (5) large trader were got license from trade and industry offices of the district and providing beef cattle to terminal markets like Addis Ababa and Adama giving for those who are direct live animal exporters. Large traders are mainly involved in buying beef animal from small trader and producers in larger number than any other actors and supplying them to consumers and large traders in and out of the district. They keep animals usually for a maximum of weeks and above. Survey result indicates that larger markets are the main collecting centers for beef cattle in their respective surrounding areas and to Jimma and Addis Ababa market. They have better transport and communication access than other traders. Almost all large traders have collecting and transporting beef cattle by cars in a market either self-owned or rental basis.

V. Butchers

There are six (6) butcher houses that were working on meat in the district that has licenses given from the trade and industry offices. These are the final link in the marketing chain who delivers beef to end users or consumers. Their purchasing capacity was less than that of large trader and small trader because of shortage of initial capital for business. All butchers have mobile telephone to exchange current information. butchers use rented and their own house because some butchers house is found in front of the main road to attract meat buyers. They are very numerous as compared to large traders and small traders and their function was to sell to consumer and hotels in pieces after receiving larger number from large traders and small traders or producers.

\section{Hotel and restaurant}

Hotel and restaurant owners are the value chain actors during value chain analysis. They purchased either dressed raw meat from butchers or fattened beef cattle from producers to supply raw meat to the consumers. During the study their where (8) hotels (six small and 2 large) the hotel/ restaurants/ selling various type of meal consisting beef to the consumers.

VII. Consumers

They are (30) consumers are interviewed as the end users of beef cattle products in the study areas. They consume beef products either purchasing or producing. In beef cattle value chain from the design of production to the distribution of beef products to consumers, it is important to carry out the demand of the products based on consumer's preference. This implies consumers are one of the most important customers of producers, large traders 
and butchers. The reason is lack of skills of beef cattle value chain actors on quality standards there by hinder the distribution of beef products. Private consumers purchase beef cattle directly from producers and large traders though most of the consumers purchase from small traders. Farmers also make important segment of the rural consumers since they consume part of their produces during festivals.

\section{i. $\quad$ Supporting Service}

Service provision is necessary for value chain actors to perform the activities that add value and reduce transaction cost. Access to information, knowledge, technology and finance determines the state of success of value chain actors. Thus, there were different supportive service providers in my study areas.

Agriculture and natural resources offices: This actor plays an important role in beef production and increasing marketing of beef. This sector contributes for beef cattle production by structuring, providing and coordinating extension or development agents for each kebeles households under their supervision. This organization provides training, adoption of new technologies of production, input in collaboration with cooperatives/unions such as vaccine increase productivity of this essential livestock to raise farm income.

Livestock development offices: this sector also play important role in production and productivity of the whole livestock in the district, providing training for veterinary to keep the health of beef cattle as well as all animals reared by farmers and providing some inputs like that of agricultural offices specifically for that sector and services like abattoirs.

Brokers: Is serving as mediator between buyers and sellers in beef cattle market, they are usually expected to link buyers with sellers and facilitate the term of exchange or transaction. even though there were anybody who is in place or farm considered as broker by doing so, they receive brokage fee both from buyers and sellers. The brokage charge during survey time was 40 ETB per head of cattle marketed 20 ETB from buyer and 20ETB from seller.so the broker share that whatever there is number is their interference is immense in their transaction of the beef cattle are based on body condition and eye- ball estimation.

\section{ii. $\quad$ Finical services providers}

Oromia Credit and Saving Institution: It is a part of microfinance institution which provides credit services for smallholder beef cattle producers in the study area. It is a major source of financial service farmers and urban peoples including small trader and butchers, but not for large traders because of they are efficient to get credit from banks and it stands to finance smallholders and financially inefficient actors. And also this institution helps its users by holding saving money which is given to them when they leave out their service. All farmers are not benefited from this institution because of farmers has less awareness about how to use money obtained from this institution for production rather than family consumption.

Banks: It is the most financial source for large traders by providing credit services in a long term or short term. Most of large traders in the district are getting credit service from this institution and from each other. It is the only source of credit for larger traders in the district because of the prefers huge capital for trading activities than butchers, small traders.

Trade and Industry offices: It plays a major role in coordinating all private and hotel and restaurant, traders by providing licenses, training, collecting legal payments from traders to increase government revenue for public welfare. This organization coordinates and manages each and every each of beef traders in the district and works to create competent firms who create job opportunity for next generation in a sustainable manner.

Municipal slaughtering service providers: They add value by changing the beef cattle into beef meat. First they slaughter and remove the hide from the carcass (primary processing) and Splitting and cutting of the carcass into different forms based on the natural beef sections and finally arrives at the beef ready for consumption based on the interest of butchers and the consumers.

NGO: The name of NGO was Ethiopian evangelical church mikan yesus gibe integrated. They Construction of veterinary clinic and providing training on Beef, Dairy, small ruminant animals, and Poultry as well as the provide finance for females in order to improve their livelihood of their family.

iii. Extension service providers

In the study areas extension service providers are GOs, Das and WAO were the main sources of training in district. The survey result revealed that $86.8 \%$ of sample respondents participated training that were organized in the district. The result shows that most of the trainings were given on beef cattle production and the other trainings such as fattening, season of production of beef cattle, housing and watering, disease management, on crop and livestock integrating farming system and marketing are given on different agricultural activities.

\subsubsection{Beef cattle value chain mapping}

Value chain analysis systematically maps the actors participating in the production, distribution, processing, marketing and consumption of a particular product. Value chain mapping is defined as drawing a visual representation of the chain, which involves various linkages among the beef cattle actors.

According to (McCormick and Schmitz, 2002), value chain mapping enables to visualize the flow of the product from conception product design to end consumer through various actors. It also helps to identify the different actors involved in the beef cattle value chain and to understand their roles and linkages. The value chain 
map depicts the flow of beef cattle products in the market, activities carried out at each stage of the value chain, the structure of actors and the support involved in the value adding process.

Hence direct actors along beef cattle value chain in district are input suppliers, producers, small traders, large trader, butchers, hotels /restaurant, and consumers in the district. In addition to this, governmental organization such as Agricultural Office, livestock development office, Trade and Industry Office are the major supportive service providers for the actors along beef cattle value chain. Therefore, the actors, their roles, the distribution of beef cattle products and the flow of information between the actors in Nono Benja district was depicted

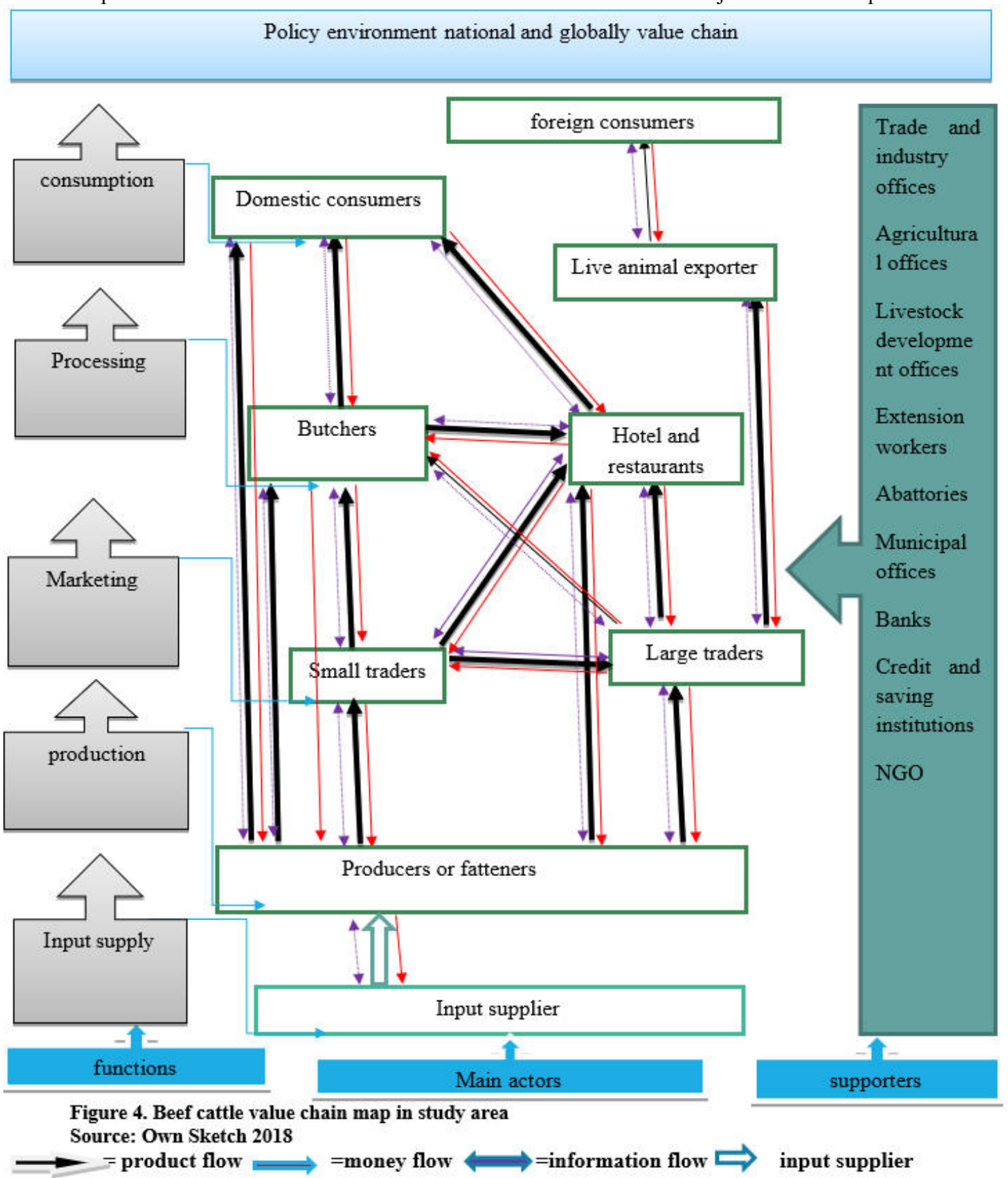

2.2.3. Value chain governance along beef cattle value chain

Value chain governance indicates the power dynamics wielded by different kinds of actors along value chain. Governance ensures that interactions between actors along a value chain organization. The governance of value chains emanates from the requirement to set product, process, and logistic standards, which then influence upstream or downstream chain actors and results in functions. But in study area small holder farmers have no access to market information and the price of their products governed by large traders. 
The governance structure gives information about the position of the producers in the chain and the relations between producers and consumers. The producers position in price setting power is weak in the study area. Due to lack of reliable market information and not organized producers heavily depend on traders. Hence, they are price takers and hardly negotiate the price. From focus group discussion producers reported that co-ordination among the value chain actors is weak and also there is asymmetry in information and knowledge sharing among the chain.

The analysis made indicated that the large traders being the main beef value chain governors. Moreover, the study also revealed that the governance structure exercised was favorable to large traders and butchers leaves producers and consumers in a weak position. Large trade has sufficient information about the supply of beef and which direction it flows along the marketing channels and markets in different parts of local market in the district. The large traders and small traders in district markets are well networked with each other's. They exchange information on prices, local supply situation in their area. Then, they agree on the price at which the buyer is willing to pay so that the seller determines the producers price taking in to account their profit margins.

In general, the governance structure in the study area was characterized by low coordination among the value chain actors in information exchange and knowledge transfer and low involvement in changing the rules and regulations that was exercised in the study area. Therefore, there is a need to make intervention to improve coordination mechanism among the value chain actors and encourage all actors in changing the existing system that was exercised in the study areas.

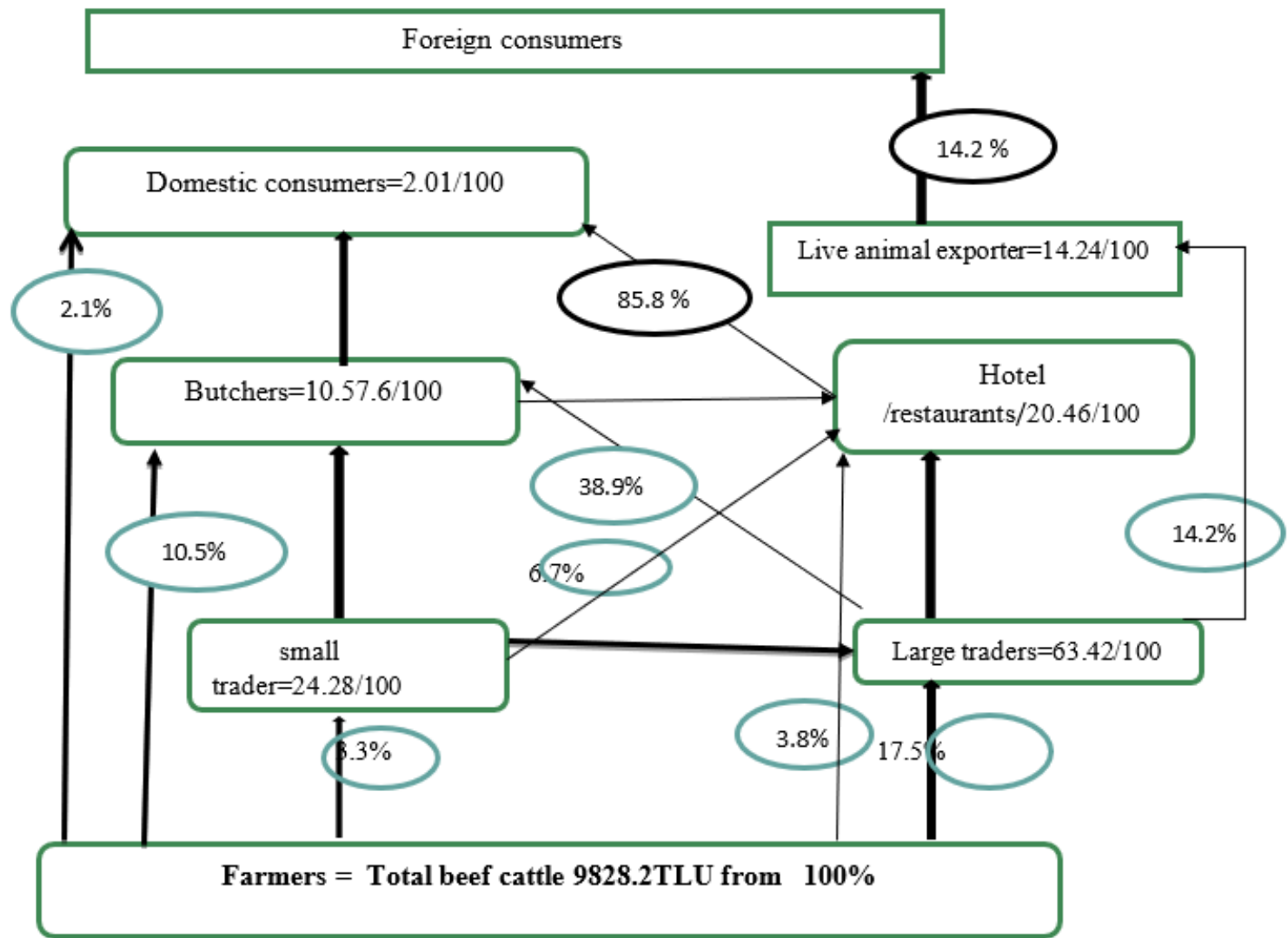

Figure 1. The marketing channels of Beef cattle in study area.

Source: own sketch 2018

\section{Beef cattle Marketing channels of Actors}

The beef cattle market channels were evaluated based on the level of marketing shares and also the level of market integration among the major markets actors. In the study area there is eight marketing channels. The analysis of marketing channels was intended to provide a systematic knowledge of the flow of goods and services from its origin to final purpose. In order to describe the market performance of beef cattle using the margin concept, the following ways of beef cattle have been identified from the existing market. During 2017/18 beef cattle supplied to the market is through all channels were 10,028.19 TLU.

Channel I: Producers

Channel II: Producers

Channel III: Producers

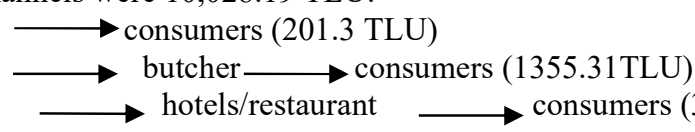
consumers (374.93TLU) 


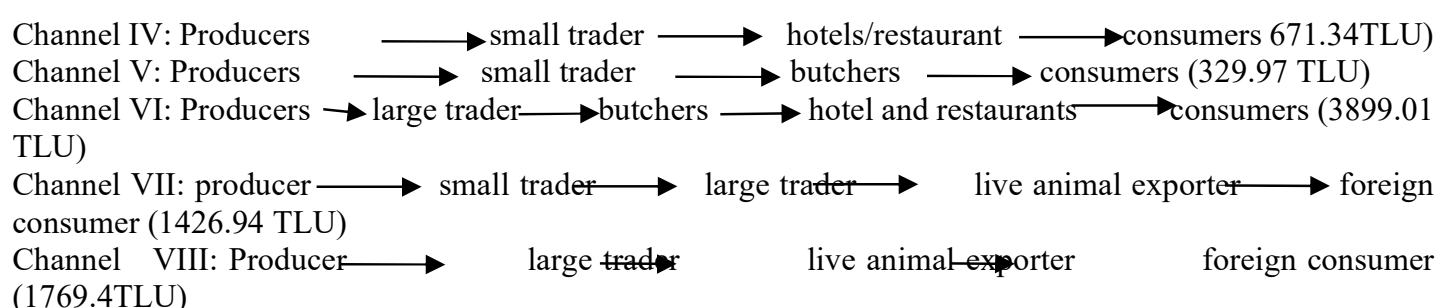

\subsection{Beef cattle market channels}

\section{Channel I; producers $\longrightarrow$ consumers (201.3 TLU or $2.1 \%$ )}

This is direct sale of animal by producers to consumers this is the shortest channel in livestock marketing in the study areas.in this case producer gets all margins since there is no intermediary to share the medium of consumers benefit from such transaction since price are not inflated due to marketing and other intermediaries cost. This channel is common during holiday and festivals. encouraging such direct transaction between producers and consumer would boost the proportion of final price of animal that would accrue to producers

\section{Channel II: producers $\longrightarrow$ butchers $\longrightarrow$ consumers (1355.34 TLU or 13.5\%)}

This second shortest channel because there are no intermediaries between producers and buyers this is the best channel animal transacted mainly male fattened ox/bull and fattened cow that is mainly transacted.in this channel all the consumers, buyers and sellers benefit from the transaction because the bargaining their prices and get margins that would normally obtained by intermediaries. the buyer and consumers also benefits since there are few transaction cost and the margin added by several intermediaries are not included this encourage producers to produce more and the buyer to beef meat since the get animals alternatively at lower prices at that area.

\section{Channel III: procedures $\longrightarrow$ hotel/restaurant $\longrightarrow$ consumers (374.93 TLU or 3.8\%)}

This also the second shortest channel because there are no intermediaries between producers and buyers the type of animal in this channel is mainly male fattened ox/bull and fatten cow that is mainly transacted. In this channel both buyers and sellers benefit from the transaction because producers can bargain their price and get margin that would normally be obtained by intermediaries. the buyers also benefit since there are few transaction cost and the margin added by several intermediaries are not included. This encourage the producers to produce more and the buyers to beef meat since the get animals alternatively lower price at that area.

Channel IV: producers $\longrightarrow$ small trade $\longrightarrow$ hotel/restaurant $\longrightarrow$ consumers $(671.34 T L U=6.7 \%)$ in this channel collectors buy in small market in the bush and/ or primary livestock market specially from maxo market and sell to hotels /restaurants in the district town .in this market channel hotel/ restaurant business boom when no fasting due to the orthodox Christian and consumer number is high the type of animal transacted in the channel are mature fattened bull/ox and unproductive cow or unfertile heifers.

Channel V producers $\longrightarrow$ Small trader $\longrightarrow$ butcher $\longrightarrow$ consumers $(329.97$ TLU $=3.3 \%)$

In this channel small traders buy in small market in the bush and /or livestock market Maxo market and sell to butchers in the District town. Butchers business boom when no fasting due to orthodox Christian and price is good. type of livestock transacted in this channel are mature fattened bull, ox and unproductive cow or unfertile heifers.

Channel VI: producers $\longrightarrow$ small traders $\longrightarrow$ larger trade $\longrightarrow$ butcher $\longrightarrow$ hotel and restaurants $\rightarrow$ consumers (3899 TLU=38.9\%)

This channels are big towns like Jimma, Addis Ababa, Adama and Harar is channel for highly fattened and grade one and two type of beef cattle.in this channels animals changed hand many times before reaching the final consumers. this means each of actors involved in a margin and this inflates the price of animal /meat to the final consumers. the final price does not reach the producers.it eventually affect meat domestic consumers.

Channel VII producers $\longrightarrow$ small traders $\longrightarrow$ Larger tratter $\longrightarrow$ live animal exporter $\longrightarrow$ foreign
consumers (1426.94 TLU=14.2\%)

This channel where by live animal exporter based in Adama area receive from larger trader live animal exporter receive from small trader at market such as Jimma, Shanan, benja from Alga and benja markets the transact animals and give for large traders where area of road accessibility is there. the live animal exporter conformation of animal's body for 2-4 months and export to Gulf countries through the port of Djibouti. This channel mainly dedicated intact male cattle whose age ranges from 3-7 years with more emphasis of age 5-7 years.

\section{Channel VIII producers $\longrightarrow$ large trader $\longrightarrow$ live animal exporter $\longrightarrow$ foreign}

consumers (1769.41TLU=17.69\%)

This is channel where by live animal exporters those in Adama from large traders, large trader buys directly from producers at market such as Benja and Alga market. The larger trader use truck to transport and deliver the live animal exporter. The live animal exporter conformation of the animal for 2-4 months and export to gulf countries through port of Djibouti. This channel is mainly dedicated to intact male cattle whose age ranges from 3-7 years with more emphasis dominance of age 5-7 years 


\subsection{The Benefit Share of Each Actor in the Beef Value Chain}

4.1.1. Value added and benefits share calculations

Added value may be defined as the incremental value to a commodity as it undergoes processing in the production stream. added value is defined as the difference between output value and the input cost. The sum of the added value created by each actor produces the total added value for overall supply chain. Value added/profit is the difference between revenue and the total cost.

The actors in beef value chain at each level incur input costs and make different value addition activities on the product in different forms at each stage and they get certain amount of benefit or (profit). This study used the value between the revenue and total costs incurred as value added on the product at each stage along the beef value chain. In the study areas, the main beef value chain actors have been participating in three major sized beef cattle types such as small, medium and large. Therefore, the value added and benefit share calculations for the single medium sized beef cattle types and the average value added as well as value share calculations are depicted in Tables 7 below. Moreover, I preferred to use the formula below for the value share calculations formula mentioned under methodology section which gives the result and more clearly than the previous because it uses the sum of the average value added by main chain actors along the chain. The formula used for calculation is as follows: Value share equals Value added by one individual actor * 100/ the sum total of values added by main actors along the beef value chain.

\subsubsection{Marketing margin}

As mentioned earlier marketing margin is the difference between the price paid by consumers and that obtained by producers. Based on the reported prices by the different market participants, summarized in the gross and net margins for different marketing actors are calculated as follows.

\subsubsection{Marketing costs}

Marketing costs are estimated to compute the share of profit captured by key actors in the marketing chain. Table 7 shows the average marketing costs incurred by every actor during transaction. Although, production cost was only incurred by beef producing farmers, they mostly incurred during the production phase rather than during marketing their produce. They expend production cost of 1528.8 birr per single beef cattle. Furthermore, in the study area, beef cattle are produced using family labour and hired labour.

Table 7. The average marketing cost and share of the main actors along the value chain for a single beef (bulls or oxen) for channel six.

\begin{tabular}{|c|c|c|c|c|c|c|}
\hline Item & Producers & $\begin{array}{l}\text { Small } \\
\text { traders }\end{array}$ & $\begin{array}{l}\text { Larger } \\
\text { trader }\end{array}$ & Butcher & $\begin{array}{l}\text { Hotel } \\
\text { restaurant }\end{array}$ & Consumers \\
\hline Purchasing prices & 4000 & 8000 & 12500 & 18050 & 21025 & 23600 \\
\hline Production cost & 800 & - & - & - & - & - \\
\hline Labour/hiring/ & 600 & - & - & - & - & - \\
\hline Veterinary cost & 128.8 & & & & & \\
\hline Total production cost & 1528.8 & & & & & \\
\hline Marketing cost & - & & 475 & 25 & 25 & \\
\hline Transport & - & 100 & 150 & 25 & 25 & \\
\hline Feed & - & 200 & 150 & 200 & 100 & \\
\hline Labour & 100 & & & & & \\
\hline Slouthering services & - & & & 100 & 100 & \\
\hline Land rent and sticking & - & 50 & 50 & & & \\
\hline Broker fee & 40 & 40 & 100 & 50 & 50 & \\
\hline Hotel and restaurant rent & - & & & 300 & 400 & \\
\hline Tax & - & 10 & 50 & 100 & 100 & \\
\hline Total marketing cost & 140 & 400 & 975 & 800 & 600 & \\
\hline Total cost /TFC+TVC/ & 5668.8 & 8400 & 13475 & 19750 & 21625 & \\
\hline Selling prices/revenue & 8000 & 12500 & 18050 & 21025 & 23600 & \\
\hline $\begin{array}{l}\text { Marketing margins /net } \\
\text { income/ }\end{array}$ & 2331.2 & 4100 & 4575 & 2275 & $1975=15256.2$ & \\
\hline Added value & 4000 & 4500 & 5550 & 2975 & 2575 & 23600 \\
\hline $\begin{array}{l}\text { Value share }=\text { added } \\
* 100(\text { consumer price }\end{array}$ & $15.28 \%$ & $26.87 \%$ & $29.98 \%$ & $14.9 \%$ & $12.90 \%$ & $100 \%$ \\
\hline
\end{tabular}

Source; Own survey result of 2018

Table 7 above shows that, beef cattle fatteners making more efforts to add value over the others in the beef value chain. When the values added are compared, the beef cattle fatteners' value is more than the beef cattle large 
traders and beef small traders in the study areas. But that does not mean that beef cattle fatteners are making more money over the others because it takes them at least three and more months to add such values to the beef cattle whereas for the other actors it takes a week or a few days. The higher percent of value added indicates that the beef cattle fatteners are performing more efforts in value addition activities over the others through changing the body weight and external look up of the beef cattle making it attractive in the eyes of the next actors in the beef value chain. In other words, it also means that the actors (large traders butchers hotel and restaurants, small traders and consumers) value share is more than the fatteners which is $82.5 \%$ but their expense is less than the beef cattle producers. That means by simply buying from the farmers and selling to consumers, other actors took $82.5 \%$ of the total profit margin. While farmers, doing all the work of producing and bearing the associated risks, took $17.5 \%$ of the profit share.

Table 7 shows that on average beef cattle fatteners are exerting more efforts in value addition activities over the others in the beef value chain conducted in the study areas. Both beef cattle producers and large traders are approximately obtaining fair value share from the beef value chain in the study areas except that some of the beef small traders and butchers are to some extent unwillingness to tell the right amount they get and also it does not mean that they are obtaining the lower share from the system because their cumulative share is more than the producer share which is $62.5 \%$. However, still it requires further investigations by the scholars for more clarification and conclusion of the whole system in the study areas particularly and the region as well as the country in general. According to the beef cattle slaughtering service providing center at Alga town information particularly (Ato Kafalo Alemu. Personal Communication) who has the long time experience in slaughtering service providing centers, the average beef weight for a single beef cattle ranges from $45-65 \%$ and the total live single beef cattle weight ranges from $200-400 \mathrm{~kg}$. If the average beef weight is calculated based on these figures for single small, medium and large sized beef cattle, it will be as follows.

Beef from single small sized beef cattle $=45 * 200 \mathrm{~kg} / 100=90 \mathrm{~kg}$

Beef from single medium sized beef cattle $=50 * 300 \mathrm{~kg} / 100=150 \mathrm{~kg}$

Beef from single large sized beef cattle $=65 * 400 \mathrm{~kg} / 100=260 \mathrm{~kg}$

If the average weight for three figures is $166.66 \mathrm{~kg}$ is taken and multiplied by the average beef price per $\mathrm{kg}$ at Alga town which is $140 \mathrm{ETB}$ and it gives $(166.66 \mathrm{~kg} * 140 \mathrm{ETB}=23,332.4 \mathrm{ETB})$ per single average weighted beef cattle sale of beef by adding values on the beef through different mechanisms.

But by considering all expected costs to be incurred by the butchers while selling beef in different forms and deducting beef cattle purchase cost from the market on average the beef butchers may get four to eight thousand ETB per single beef cattle. In parallel with this beef butchers are better tax payers than the other beef value chain actors as mentioned by the beef butcherers themselves during the data collection. If the average revenue is taken and net income is calculated for beef butchers it may be around four to eight thousand ETB on average. This figure tells that the data given by the beef butchers during data collection contradicts with the information provided by the Alga beef cattle slaughtering service providing center. On the contrary, there is also gap for the right figure/data record by the center as well as the marketing department for the beef cattle and beef.

The information about the average beef cattle weight used to show the difference between beef butchers data and the actual beef cattle weight per single beef cattle in $\mathrm{kg}$ for this study are even less than the estimated beef cattle weight by the demonstration trial conducted of dairy cattle by SPS-LMM (2010) project indicated that it was possible to attain a weight of $500 \mathrm{~kg}$ weight at 24 months of age.

\section{SUMMARY, CONCULUSION AND RECOMMANDATION}

In principle the value share of one actor in a given value chain of certain commodity should goes in line with the contribution of each actor to that commodity value chain. This means value share of one actor should be as fair as the contribution he/she has made in terms of time, money, intellectuality. The value share calculation results show that, the highest share goes to the beef cattle fatteners followed by the beef cattle Large traders in the study areas. But the real condition on the ground contradicts with this result based on the data provided by beef cattle municipal slaughter house at Alga town and which further requires additional investigations in the study areas.

This unfair value share among the actors in the beef value chain is may be because of weak market chain, gap in market information, weak coordination among the actors, and weak management of the marketing department. In case of value additions producers, large traders, butchers, hotel and restaurants and small traders respectively contributing in value adding activities and shares. Generally, it indicates that there is very weak value chain governance along the beef value chain in the study areas. Therefore, the beef value chain governance activities in the study areas particularly and the whole beef value chain in the region as well as the country in general should be taken under consideration by the regional and central government for the future success of the beef industry and hence approximately equally benefiting the beef value chain actors.

\section{REFERENCES}

Abbey, Avery, (2004). Red Meat and Poultry Production and Consumption in Ethiopia and Distribution in Addis 
Ababa. Addis Ababa, MSc thesis, Addis Ababa.

Addisu A. et.al,2012. Beef and feed value chain study in Adama district: Value Chain consultant, ILRI September, 2012 Addis Ababa: EIAR, DebreZeit Agricultural Research

Center, Ethiopia Pp.5

Adugna Gessesse, 2009. Analysis of fruit and vegetable market chains in Alamata, Southern

Astewel Takele, 2010. Analysis of rice profitability and marketing chain: The case of Fogera Woreda, South Gondar Zone, Amhara National Regional State, Ethiopia. M.Sc thesis presented to School of Graduate Studies, Haramaya University. 76p.

Ayele Solomon, Workalemahu A, Jabar M A and Belachew H 2003 Livestock Marketing in Ethiopia. A Review of Structure, Performance and Development Initiatives. Socio-economic and Policy Research Working Paper 52. International Livestock Research Institute (ILRI), Nairobi, Kenya. 35p.

Bailey D, Barrett C B, Little P D and Chabari F., 2015. "Livestock markets and risk management among East African pastoralists: a review and research agenda". GL-CRSP Pastoral Risk Management Project Technical Report No. 03/99. Utah State University

Backman, T. and R. Davidson, 1962. Marketing principle. The Ronal Presses Co., New York. pp. 3-24.

Berg, B., Hiss, B., Fell, S., Hobinka, M., Müller, A. and Prakash, S. 2006. Poverty orientation of Value Chains for domestic and export markets in Ghana Cape Coast, Berlin. k, WDC.

Berhanu Kuma, 2012. Market Access and Value Chain Analysis of Dairy Industry in Ethiopia: The Case of Wolaita Zone. Haramaya University, February 2012. Science, Engineering and Technology Research. 2(1):1-9.

Berihu H, Aleme A, Mulata H (2014). Constraints of Livestock Development in Eastern Zone of Tigray; the case of "GantaAfeshumWoreda" Northern Ethiopia. Agricultural

COMESA /ACTESA (2011) Ethiopia Livestock Value Chain Baseline Study.

Cramer, G. and W. Jensen, 1982. Agricultural economics and agribusiness, 2nd Edition. McGraw Hill Book Company, USA. 222p.

CSA (2005/06) Livestock and livestock characteristics; Private peasant holdings; \# 364, CSA, Addis Ababa, Ethiopia.

CSA (2008) Research Project ETH/92/P01 Central Statistical Authority (CSA) Addis Ababa, Ethiopia Institute for Population Research - National Research Council (Irp-Cnr) Roma, Italy.

CSA (Central Statistical Agency). 2013. Livestock and livestock characteristics 2012-13 (Private peasant holdings). Statistical Bulletin No. 570. Addis Ababa, Ethiopia: CSA.

De Haan (2013) Diagnostic trade integration study - livestock and meat sector: challenges and opportunities. Agriculture and Rural Development Department, The World Bank: Washington DC, USA

Delgado, C., Rosegrant, M., Steinfeld, H., Ehui,

Dolan, C.S. and J Humphrey (2000), 'Governance and Trade in Fresh Vegetables: Impact of UK Supermarkets on the African Horticulture Industry', World Development, 37 (2): 147-77.

Dries, L and J.F.M Swinnen (2004), 'Foreign Direct Investment, Vertical Integration, and Local

FAO (Food and Agricultural Organization). 2012. Addressing marketing and processing constraints that inhibit agri-food exports: a guide for policy analysts and planners. Agricultural Service Bulletin 160. Rome. Italy. $109 \mathrm{p}$

FAO. 2009. State of Food and Agriculture (SOFA). Livestock in the balance. FAO, Rome, Italy.

FAOSTAT, 2004. Food and Agricultural Organization of the United Nations.; Retrieved July 15, 2004 from FAOSTAT on-line database, http://faostat.fao.org/defualt.jsp?language=EN\& version $=$ ext \& has bulk=0.

FAPRI-ISU, 2015, Charles F.; STEPHENSON, Mark W. Milk price cycles in the US dairy supply chain and their management implications. Agribusiness, v. 31, n. 4, p. 507-520, 2015.

Gashahun gezagne, 2015. Beef cattle value chain analysis in case of Darimu district, Ilu Abbor Zone Southe Western of Oromia regional state, Ethiopia. unpublished thesis.

Gebre Mariam S., Amare S., Baker, D., Solomon, A. and Davies, R. 2013. Study of the Ethiopian live cattle and beef value chain ILRI Discussion Paper 23; Nairobi: International Livestock Research Institute international center, Austria. United Nations industrial development organization.

Gereffi, G. 1994. The Organization of Buyer-Driven Global Commodity Chains: How U.S. Retailers Shape Overseas Production Networks, in Gereffi, G. and Korzeniewicz, M. (eds). Commodity Chains and Global Capitalism

Getachew Lagasse., Hailemariam, T., Dawit, A. and Asfaw, N. (2008), Live animal and meat export value chains for selected areas in Ethiopia: Constraints and opportunities for enhancing meat exports, discussion paper No 12, people livestock and environment ILRI.s

GTZ (Deutsche Gesellschaftfür Technische Zusammenarbeit GmbH) 2007 Value Links Manual: The Methodology of Value Chain Promotion, First Edition. Found at Internet address http://www.valuelinks. de/manual/distributor.html Hall D.C et al, 2004. The livestock revolution, food safety, and small-scale farmers: Why they matter to us all. Journal of Agricultural and Environmental Ethics, 17: 425-444. 
Gujarati, D. 2004. Basic of Econometrics, 4th edition. McGraw hill Company, IN United States Military Academy, West point.

Hailesilassie, H., 2016. The effect of improved fodder production on livestock productivity in Endamehoni District, southern Tigray Ethiopia (Doctoral dissertation, Mekelle University).

Holloway, G. and S. Ehui, 2002. Expanding market participation among smallholder livestock producers: A collection of studies employing gibbs sampling and data from the Ethiopian highlands. Socio-economic and Policy Research Working Paper 48. ILRI, Nairobi, Kenya. 85p.

Holt,T., 1993. Risk response in the beef marketing channel: a multivariate generalized arch-m approach. American Journal of Agricultural Economics, 75: 559-571.

ILRI (2008) Working Paper No. 19, Cattle milk and meat production and marketing systems and opportunities for market orientation in Fogeraworeda, Amhara region, Ethiopia

Jansen, A. 2007. Value Chain Finance: Understanding and Increasing Access. A Concept Paper. USAID

Joseph Hain, Linda Logan and Stephen Collins (2015): Evaluation of Sanitary And Phytosanitary (Sps) Trade Policy Constraints Within The Maize And Livestock/Animal-Sourced Products Value Chains In East Africa, Leo Report \#12.

Kaplinsky R and Morris M 2001 A Handbook for Value Chain Research. Working Paper Prepared for the IDRC, Brighton, UK, Institute for Development Studies.

Kefyalew Alemayew. 2011, Value chain assessment of beef cattle production and marketing in Ethiopia: Challenges and opportunities of linking smallholder farmers to the markets. kefyale@gmail.com

Kemal Hussine. 2010. Analysis of small marketing system in Southern Oromia National Regional state.

KindeAysheshm. 2007. Seasome market chain analysis: the case of Metema district, North Gonder Zone, Amhara National Regional State.

Kohls, R., and N. Uhl, 1985. Marketing of agricultural products. 5th Edition. McMillian Publishing Company, NewYork, USA.

LDMPS 2007. Livestock Development Master Plan Study. Phase I Report - Data Collection and Analysis. Volume $\mathrm{O}$ - Livestock and Products Marketing. Ministry of Agriculture and Rural Development. November 2007

Lerman Z. 2004. Policies and institutions for commercialization of subsistence farms in transition countries. Journal of Asian Economics 15:461-479.

Livestock and Livestock Characteristics. Rep. Vol. II. Addis Ababa: Federal Democratic Republic of Ethiopia, 2012.

LMD Research Interviews and Reports. Unpublished research documents from LMD Research, 2012-13

Maddala, G.S. 2001.Introduction to Econometrics. Third Edition, John Will.

Mendoza, G. 1995. A Primer on Marketing Channels and Margins: Lyme Rimer Publishers, USA.

Million Tadesse, 2014. Factors Influencing the Adoption of Soil Conservation Practices in Wolaita Zone. The Case of Gununo Area MSc Thesis, Department of Agricultural Economics, Alemaya University.

Ministry of Agriculture and Rural Development (2013). Major challenges and Achievements in Ethiopian Livestock production.

Ministry of Agriculture and Rural Development. Agricultural Growth Program (AGP), Program Implementation Manual (PIM). Rep. Addis Ababa: Federal Democratic Republic of Ethiopia, 2010

Ministry of Finance and Economic Development, (2009)

Miressa Regassa ,2015. Determinant of fertilizer on potato production in case of Nono Benja District Jimma zone, Oromia regional state, Ethiopia. unpublished thesis.

MoA (Ministry of Agriculture), 1997b. Ruminant Livestock Development Strategy, Addis Ababa, pp: 87.

Muhammed Urgessa, 2011. Market chain analysis of teff and wheat production in halaba special woreda, southern Ethiopia. M.Sc thesis submitted to the School of Graduate Studies, Haramaya University. 104p.

NBLO,2017. Nono Benja livestock development offices Source Edicts that livestock population of the District was classified in to four groups.

Negassa, Asfaw. and Jabbar, Mohammad. 2008. Livestock ownership, commercial off-take rates and their determinants in Ethiopia; ILRI Research Report No. 9 Nairobi: ILRI (International Livestock Research Institute). National Bank of Ethiopia 2005/2006

Neven D, H Katjiuongua, I Adjosoediro, T Reardon, P Chuzo, G Tembo and M Ndyiyoi (2006), 'Food Sector Transformation and Standards in Zambia: Smallholder Farmers Participation and Growth in the Dairy Sector.

Nigussie Tesfaye, 2014. The Productivity and Profitability of Wheat and Teff Technologies in Selected Villages of Ethiopia. M.Sc. thesis presented to Addis Ababa University, Addis Ababa, Ethiopia. (Read more at http://www.yourdictionary.com/cattle\#y54z4F2ip54FpPCd.99

Oume et al., 2010. feeding animals, health and genotype should improve in Ethiopia

Pastoral Community Development Project (2007). Review of Development Policies and Strategies Related to Pastoral Areas in Ethiopia

Porter ME. 1985. Competitive Advantage. Free Press, New York. Pp.557. Publishing. 
Porter, M. 1990, The Competitive Advantage of Nations, The Macmillan Press LTD, London and Basingstoke.

Rabobank, 2010. Global Focus: Australian Beef. Utrecht, the Netherlands.

Rich, K.M., Ross, R.B., Baker, D.A., and Negassa, A. 2010. Extending value chain analysis to livestock systems in developing countries.

Schipmann, CH. 2006. Value chains for a better integration of smallholders to trade; the case of chilli in Ghana. Master Thesis, Humboldt-University, Berlin, Germany.

Scott, G.J. 1995. Prices, Products and People: Analyzing agricultural markets in developing countries. Lynne Reinner Publishers, Boulder, London.

Sintayehu et al, 2013. Study of the Ethiopian live cattle and beef value chain, ILRI Discussion Paper No. 23 SPSLMM (Sanitary and Phytosanitary Standards and Livestock \& Meat Marketing Program). 2009.Unpublished project data and records.

Sintayehu Gebremariam., Samuel Amare., Derek B. and Ayele Solomon., 2010. Diagnostic study of live cattle and beef production and marketing constraints and opportunities for enhancing the system.

Solomon Tilahun. 2004. Performance of Cattle Marketing System in Southern Ethiopia with Special Emphasis on Borena Zone. A Thesis Submitted to Postgraduate program Alemaya University, Alemaya.

Solomon, et al (2010), Sheep and Goat Production Systems in Ethiopia, Ethiopian sheep and goat Productivity improvement program

Storck, H., Bezabih Emana, Berhanu Adnew, Borowiecki, A.A and ShimelisWoldeHawariat. 1991. Farming systems and farm management practices of small-holders in the Hararghe Highlands." Farming system and resource Economics in the Tropics. 11: WissenschaftsVarlagVauk Kiel KG, Germany

Takele et.al, 2009. Traditional Backyard Cattle Fattening in Wolayta: Systems of Operation and the Routine Husbandry Practices. Ethiopian Society of Animal Production (ESAP) ISSN: 1607-3835 Volume 9, Number 1,2009

Tanga, F.K., M.A. Jabbar and B.I.Shapiro. 2000. Gender roles and child nutrition in livestock production systems in developing countries: A critical review. Socio-economics and Policy Research Working Paper 27. ILRI (International Livestock Research Institute), Nairobi, Kenya. 64p.

Target 2008. Livestock Value Chain Study; Especial Emphasis to DhasWoreda of Borena Zone, Oromia Regional State, Action for Development, Addis Ababa, Ethiopia. Studies by Target Business Consultants Plc.

Teklewold, H., Legesse, G. and Alemu, D. 2009. Market structure and function for live animal and meat exports in some selected areas of Ethiopia. EIAR Research Report No. 79. Addis Ababa, Ethiopia: EIAR (Ethiopian Institute of Agricultural Research).

UNDP-EUE, 2002. A support unit for the United Nations system in Ethiopia, UN emergencies unit for Ethiopia welcome to the UN-EUE home page, Addis Ababa, Ethiopia. World Bank (2002)

Upton,2014. rural livelihood improvement and augmenting livelihood of poor are being recognized.

Webber, M. and Labaste, P. 2009. Building Competitiveness in Africa's Agriculture: A Guide to Value Chain Concepts and Applications. World Bank Agriculture and Rural Development Series, World Bank

Wondatir, Zerihun. (2010). Livestock production systems in relation with feed availability in the highlands and central rift valley of Ethiopia.

Wolday Amha, 1994. Food grain marketing development in Ethiopia after Reform 1990. A Case Study of Alaba Siraro. The PhD Dissertation, Verlag Koster University. Berlin 293p.

World Bank ,2013 World Bank. 2008. Agriculture for development. World Development Report 2013.The World Bank,

WashingtonD.C.,USA.http://www.econ.worldbank.org/website/external/extdec/extresearch/extwdrs/extwdr2 008/www.americanij.com 51 | A M E R I C AN I J Volume 12014 ISSUE 2 June-July AIJCSR

World Bank. 2009. Minding the stock: Bringing public policy to bear on livestock sector development. Report No. 44010-GLB. The World Bank, WashingtonD.C., USA.

Yaicob Aklilu (2007) "An Assessment of Supply and Demand Issues for the Ethiopian Meat Export Industry" (unpublished) Addis Ababa.

Yigezu, Yared et al 2014. Ethnoveterinary medicines in four districts of Jimma zone, Ethiopia: cross sectional survey for plant species and mode of use. BMC veterinary research, 10(1), p.76. 